\title{
Effect of physicochemical character differences on the genotoxic potency of kaolin
}

Tatsuya Kato ${ }^{1}$, Tatsushi Toyooka ${ }^{2,4}$, Yuko Ibuki ${ }^{2}$, Shuichi Masuda ${ }^{2}$, Masatoshi Watanabe ${ }^{3}$ and Yukari Totsuka ${ }^{1 *}$

\begin{abstract}
Background: Kaolin is white clay mineral with the chemical composition $\mathrm{Al}_{2} \mathrm{Si}_{2} \mathrm{O}_{5}(\mathrm{OH})_{4}$, and many varieties of kaolins having different crystal structures are utilized in industrial, cosmetic and medical fields. To evaluate the effect of physicochemical character differences on the genotoxicity of kaolin, two types of kaolin, kaolin-S with smooth, sphere-shaped crystals, and kaolin-P with clusters of thin pseudohexagonal plates, were used in the study.

Results: ICR mice were intratracheally instilled with the kaolins (0.05 and $0.2 \mathrm{mg} / \mathrm{mouse}$ ), and comet assay was performed on their lungs. Both kaolins showed DNA damage in the lungs of the mice, however the DNA damaging potency was much higher with kaolin-P than that with kaolin-S.

In order to clarify the mechanisms for the different genotoxic potency, we examined the incorporation rate and ROS generation of these two types of kaolin in alveolar epithelial A549 and macrophage-like RAW264 cells, using flow cytometric (FCM) analysis. Kaolin-P showed a higher incorporation rate into the mammalian cells and ROS generation than that of kaolin-S. Especially, RAW264 cells aggressively incorporated kaolins, and generated ROS, whereas almost no ROS generation was observed in A549 cells. In addition, inflammatory cytokines were quantified, using the ELISA method, to understand further genotoxic potency differences of kaolins. Concentrations of interleukin-1 $\beta$ (IL-1 $\beta$ ) and tumor necrosis factor-a (TNF-a) in the media were increased by exposure to both kaolins, but in the case of kaolin-P, these inflammatory cytokines were significantly elevated. Based on these findings, differences of genotoxic potency may contribute to incorporation rates into immune cells. Furthermore, it is likely that immune cells and epithelial cells might closely interact with each other for the appearance of genotoxocity in vivo. In order to clarify the interaction between epithelial and immune cells, A549 and RAW264 were co-cultured and RAW264 cells only were exposed to kaolins, then subsequently A549 was applied to FCM analysis and comet assay. DNA damage observed in the A549 cells markedly increased in the presence of kaolin-exposed RAW264 cells compared to the single culture.

Conclusion: From these observations, it is suggested that mechanisms of kaolin genotoxicity against epithelial cells are through the activation of macrophage cells. Therefore, it is thought that interactions between epithelial and immune cells would be very important for evaluation of the genotoxicity of fine particulate matter. We also showed here that co-culture models of epithelial and immune cells could be used as suitable models for evaluation of lung genotoxicity of fine particulate matter, including nanomaterials, as in vivo mimicking systems.
\end{abstract}

Keywords: Kaolin, Genotoxicity, Co-culture

\footnotetext{
*Correspondence: ytotsuka@ncc.go.jp

${ }^{1}$ Division of Carcinogenesis and Cancer Prevention, National Cancer Center

Research Institute, 1-1 Tsukiji 5-chome, Chuo-ku, Tokyo 104-0045, Japan

Full list of author information is available at the end of the article
} 


\section{Background}

Kaolin is a naturally occurring white clay mineral with the chemical composition $\mathrm{Al}_{2} \mathrm{Si}_{2} \mathrm{O}_{5}(\mathrm{OH})_{4}$. A large amount of kaolin is primarily used in the paper industry both as a filler and as a coating for paper. Other applications of kaolin include use in the ceramics industry, cosmetics, and pharmaceuticals [1]. We have previously reported that kaolin showed genotoxic effects in in vitro and in vivo assay systems [2, 3]. Recently, there have been many reports that toxicity induced by fine particles is influenced by physicochemical differences such as size [4-9]. The chemical structure of kaolin is a two-layer silicate and is known to consist of a silica tetrahedral layer covalently bonded to an alumina octahedral layer through an apical oxygen atom [1]. Kaolinite is found as pseudo-hexagonal triclinic crystals and generally interacts between face-face, face-edge, and edge-edge surfaces to make an aggregate form [1]. Therefore, various sizes, zeta-potentials, and surface structures exist in the industrial mineral commodity of kaolins, and they are widely distributed for many intended uses. However the influences of physicochemical differences of kaolins on genotoxicity are not fully understood, yet. To verify the genotoxic effects of two kinds of kaolins representing different surface structures (one is smooth, sphereshaped crystals named kaolin-S, and the other is clusters of thin pseudohexagonal plates named kaolin-P), here, we examined the DNA damaging potency with comet assay in in vivo and in vitro. The incorporation into mammalian cells and their ROS generation using flow cytometric (FCM) analysis were also investigated. In the present study, both kaolins showed DNA damage in the mice of lungs, however the DNA damaging potency was much higher for kaolin-P than that for kaolin-S. This potent genotoxicity of kaolin-P was also supported by the results obtained from analysis of the incorporation rate, ROS production and inflammatory cytokine generation. Furthermore, aiming to examine the mechanisms involved in the appearance of genotoxic potential differences in vivo induced by kaolin-S and -P, we conducted genotoxicity analysis using a co-culture system with lung epithelial A549 and macrophage-like RAW264 cells as an in vivo mimicking system. In the present study, possible mechanisms and importance of cell-cell interactions for genotoxicty induced by kaolin are also discussed.

\section{Methods}

\section{Materials}

Kaolin-S and kaolin-P were purchased from Takehara Chemical Industrial Co., Ltd. (Okayama, Japan) and Mineral and Pigment Solutions Inc. (NJ, USA), respectively. Kaolin-S is used for medical and pharmaceutical products and kaolin-P is used for industrial products. Both kaolins were suspended in saline (Otsuka
Pharmaceutical Co. Ltd., Tokyo, Japan) containing 0.05\% of Tween 80 (Nacalai Tesque, Kyoto, Japan) by sonication for $15-20 \mathrm{~min}$, at a concentration of $2 \mathrm{mg} / \mathrm{mL}$, as a stock solution. Crystal appearance observed under a scanning electron microscope (SEM) was done by AKIT Corporation (Gifu, Japan). The size distributions of kaolins used in the present study was analyzed by dynamic light scattering (DLS) using FPAR-1000 (Otsuka Electronics Co., Ltd., Osaka) as described previously [2]. Physical characterization of particles such as zeta-potential was done by UBE Scientific Analysis Laboratory, Inc. (Yamaguchi, Japan). Type I agarose, low melting point agarose, dimethyl sulfoxide and Triton X-100 were bought from Sigma-Aldrich. Ethidium bromide was obtained from Merck (Darmstadt, Germany). Other chemicals were purchased from Wako Pure Chemical Industries (Osaka, Japan).

\section{Animals}

Male ICR mice (8 weeks old) were purchased from Japan SLC (Shizuoka, Japan) and were acclimatized for 1 week. Food (CE-2 commercial diet: Japan Clea Co., Tokyo, Japan) and water were given freely. A conventional room was air conditioned at $23{ }^{\circ} \mathrm{C}$ with a light/dark $(12 \mathrm{~h} / 12 \mathrm{~h})$ cycle. After quarantine for one week the experiments were conducted according to the "Guidelines for Animal Experiments in the National Cancer Center".

\section{Evaluation of in vivo genotoxicity of kaolins}

In order to evaluate the in vivo genotoxicity, alkaline comet assay on the lungs of mice was performed. Two doses of kaolins ( 0.05 and $0.2 \mathrm{mg}$ per animal) were suspended in $0.1 \mathrm{~mL}$ of $0.05 \%$ Tween 80 , then intratracheally instilled to mice ( $n=5$ for each dose) using a polyethylene tube under anesthesia of $4 \%$ halothane (Takeda Chemical, Osaka, Japan). The control mice $(n=5)$ were instilled intratracheally with $0.1 \mathrm{~mL}$ of the solvent alone, and non-treated mice were prepared to confirm the effect of Tween 80. Mice were sacrificed at $3 \mathrm{~h}$ after kaolin instillation and lungs were removed then subsequently minced and suspended with chilled homogenizing buffer and homogenized gently with a Dounce-type homogenizer on ice. Ten microliters of each cell suspension were mixed with $90 \mu \mathrm{l}$ of $0.5 \%$ low melting point agarose and the mixture was spread on an MAS coated glass slide (Matsunami Glass Ind., Ltd, Osaka, Japan). The slide was immersed in lysing solution (2.8 M NaCl, 0.1 M EDTA-2Na, $0.01 \mathrm{M}$ Tris-base, $0.2 \mathrm{M} \mathrm{NaOH}, 10 \%$ dimethyl sulfoxide, and $1 \%$ Triton X-100, and $\mathrm{pH} 10.0$ ) and refrigerated at $4{ }^{\circ} \mathrm{C}$ overnight. Then, the slides were immersed in alkaline electrophoresis buffer (0.3 M NaOH, $1 \mathrm{mM}$ EDTA-2NA) at $4{ }^{\circ} \mathrm{C}$ for $15 \mathrm{~min}$ to allow for DNA unwinding. Electrophoresis was performed for $15 \mathrm{~min}$ at $4{ }^{\circ} \mathrm{C}(25 \mathrm{~V}, 300 \mathrm{~mA})$. The slides were neutralized with Tris buffer (0.4 M Tris-base, 
$\mathrm{pH}$ 7.5) at room temperature for $5 \mathrm{~min}$, and dehydrated with ethanol to fix. The cells on the slide were stained with SYBR Gold ${ }^{\circ}(10,000 \times$ dilution; Molecular Probes, Eugene, OR) for $10 \mathrm{~min}$, and washed with distilled water 3 times. After drying, comet images were analyzed using a fluorescence microscope (magnification 200x) equipped with CCD camera. Two slides (50 cells/slide) were prepared per mouse, and 100 cells were examined per mouse (Finally, 500 cells/10 slides were prepared from each treatment group). The percentage tail intensity was measured using Comet Assay IV (Perceptive Instruments, Ltd., Haverhill, UK). For evaluation of DNA damage, the slides were randomised and coded so that the treatment group was blinded to the scorer. The frequency of hedgehogs was not included in the data.

\section{Cell culture and treatment with kaolin}

A549 (RIKEN Cell Bank, Tsukuba, Japan) and RAW264 (RIKEN Cell Bank) were maintained in MEM (Nacalai Tesque, Kyoto, Japan) supplemented with $10 \%$ fetal bovine serum, penicillin $(100 \mathrm{U} / \mathrm{mL})$ and streptomycin $(0.1 \mathrm{mg} / \mathrm{mL})$. The cells were cultured at $37{ }^{\circ} \mathrm{C}$ in $5 \%$ $\mathrm{CO}_{2}$. All experiments were performed with exponentially growing cells.

Kaolin stock solution was diluted with MEM at suitable concentrations, and sonicated for $10 \mathrm{~min}$. A549 and RAW264 cells were treated with each kaolin at specific concentrations $(20-200 \mu \mathrm{g} / \mathrm{mL})$ and incubated for a predetermined time (30-180 min). After treatment, kaolin was removed and cells were harvested for each assay.

\section{Analysis of incorporation rates of kaolin}

The incorporation rates of kaolin into mammalian cells were measured using the FCM analysis developed in previous reports [4, 10]. Briefly, A549 and RAW264 treated with several conditions of kaolin were trypsinized and suspended in fresh culture medium. Propidium iodide (PI; $0.5 \mu \mathrm{g} / \mathrm{mL}$ ) was added to each cell suspension to determine the cell survival rates. The numbers of cells incorporating kaolin was analyzed with FACSCaliber (Becton Dickinson, Mountain View, CA). In the FCM analysis, forward-scattered (FS) light indicating cell size and side-scattered (SS) light indicating intracellular complexity were observed. The cells increasing SS were considered as material-incorporating cells, and the change in SS was an index of incorporation rates, as described previously $[4,10]$.

\section{Determination of intercellular ROS}

Intercellular ROS in the mammalian cells were measured using FCM with 2',7'-dichlorodihydrofluorescin diacetate (DCFH-DA) as described by Könczöl et al. with minor modifications [11]. DCFH-DA that has nonfluorescence can permeate the cell membrane, where subsequently it is hydrolyzed by unspecific esterases and converted into DCF that fluoresces in the presence of ROS. DCFH-DA was added into cell suspensions treated with kaolin at a final concentration of $20 \mu \mathrm{M}$, and incubated at $37^{\circ} \mathrm{C}$ for $30 \mathrm{~min}$. The cell suspensions were applied to FCM analysis, and the fluorescence was detected at an excitation wavelength of $485 \mathrm{~nm}$ and an emission wavelength of $530 \mathrm{~nm}$. The numbers of cells increasing the fluorescence level were measured as the ROS generating cells.

\section{In vitro comet assay}

DNA damaging potency of kaolin against mammalian cells was employed by comet assay using the same procedure described above (See in "Evaluation of in vivo genotoxicity of kaolins") with some modification [2]. Briefly, ten $\mu \mathrm{l}$ of $8 \times 10^{3}$ cells $/ \mathrm{mL}$ cell suspension was mixed with $90 \mu \mathrm{l}$ of $0.5 \%$ low melting point agarose and the mixture was spread on the MAS coated glass slide. After immersion in lysing solution, slides were incubated for $30 \mathrm{~min}$ at $37{ }^{\circ} \mathrm{C}$ with or without formadidopyrimidineDNA glycosylase (FPG) protein (Sigma-Aldrich, St Louis, $\mathrm{MO}$ ) in order to confirm oxidative DNA damage [12]. Thereafter, each slide was then placed in alkaline electrophoresis buffer to allow for DNA unwinding. After electrophoresis, the slides were neutralized and dehydrated, then the cells were stained with SYBR Gold ${ }^{\circ}$. DNA damage was measured by the same procedure for in vivo comet assay described above.

Co-culture with lung epithelial and macrophage-like cells To verify the interaction between epithelial and macrophage cells, A549 and RAW264 were co-cultured in the same culture medium (in vivo mimic system, Scheme 1). A549 cells were cultured in MEM with 10\% FBS for $24 \mathrm{~h}$, and subsequently RAW264 cells were seeded into cell culture inserts (pore size; $0.4 \mu \mathrm{m}$, high density, Greiner BioOne Co., Ltd., St. Gallen, Switzerland). After culture for $24 \mathrm{~h}$, only RAW264 cells were treated with $100 \mu \mathrm{g} / \mathrm{mL}$ of kaolin for $24 \mathrm{~h}$, and A549 cells, parenchymal cells, were analysed by FCM (incorporation rates, intracellular ROS generation) and comet assay with FPG treatment.

\section{Measurement of inflammatory cytokines}

Inflammatory cytokines in culture supernatant of RAW264 were measured. RAW264 cells were exposed to $100 \mu \mathrm{g} / \mathrm{mL}$ of kaolin for $24 \mathrm{~h}$, subsequently IL-1 $\beta$ and TNF- $\alpha$ were quantified using an Immunoassay Kit, Mouse IL-1 $\beta$ (BioSource International, Camarillo, CA, USA) and Quantikine ${ }^{\circ}$ Mouse TNF- $\alpha$ (R\&D Systems, Minneapolis, MN, USA), respectively, according to manufacturers' protocols. In brief, the supernatants obtained 


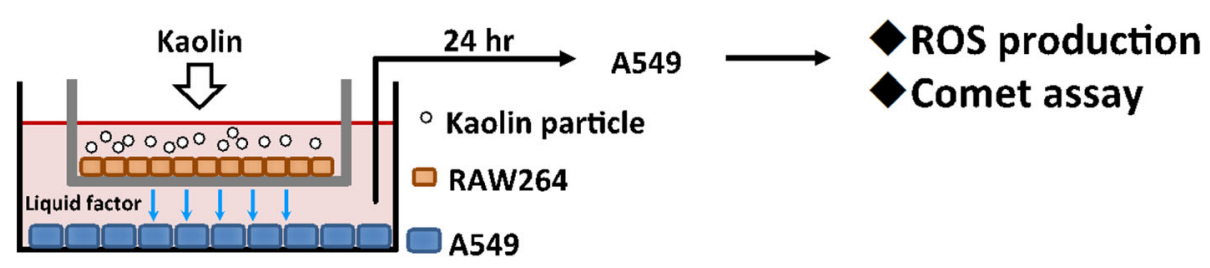

Scheme 1 Co-culture model

from culture media of RAW264 with or without kaolin treatment were transferred into 96 well plate and mixed with same volume of incubation buffer (for IL-1 $\beta$ ) or assay diluent RD1-63 (for TNF- $\alpha$ ), respectively. For detection of IL-1 $\beta$, biotinylated anti-IL-1 $\beta$ solution was added and incubated for $90 \mathrm{~min}$ at $37{ }^{\circ} \mathrm{C}$. The absorbance at $450 \mathrm{~nm}$ was measured after reaction with streptavidin-hoseradish peroxidase (HRP) and subsequent stabilized chromogen. In the case of TNF- $\alpha$ detection, monoclonal antibody for mouse TNF- $\alpha$ conjugated with HRP was subsequently reacted for $120 \mathrm{~min}$ and stabilized chromogen for $30 \mathrm{~min}$ in dark condition. Optical density at $450 \mathrm{~nm}$ (measuring) and $550 \mathrm{~nm}$ (correction) were measured and amounts of TNF- $\alpha$ were calucurated.

\section{Statistical analysis}

The data from all studies except for comet assay are expressed as the mean \pm standard deviations. The data were statistically compared using the Student's t-test.
The data obtained from comet assay are expressed as mean \pm standard errors. To test for significant differences of \% tail intensity in the comet assay between a group treated with materials and an untreated group, Dunnett's test after one-way ANOVA was used to evaluate the differences; $p$ values lower than 0.05 were considered to indicate statistical significance.

\section{Results}

Characterization of kaolins

To characterize and ascertain the properties of kaolins used in the present study, particle appearance, dispersed diameter and zeta-potential were determined. Figure 1a shows SEM images of two kinds of kaolin, kaolin-S and -P. The particles are smooth, sphere-shaped crystals for kaolin-S, and clusters of thin, pseudohexagonal plates for kaolin-P. The most abundant sizes of kaolin-S at doses of 0.5 and $2.0 \mathrm{mg} / \mathrm{mL}$ were $827.4 \pm 186.2$ and $1390.1 \pm 226.3 \mathrm{~nm}$, respectively (Fig. 1b). Those of kaolin-P were $700.0 \pm 128.6$ and $1488.3 \pm$

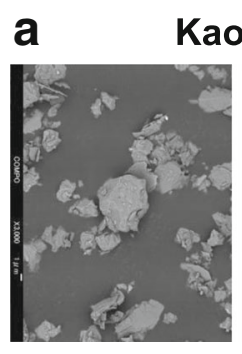

\section{olin-S}

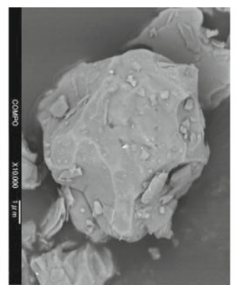

b

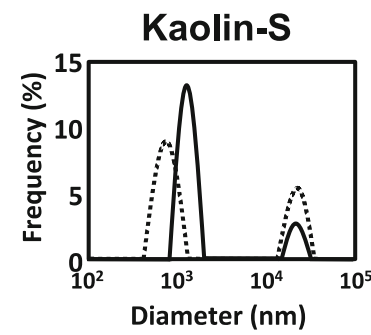

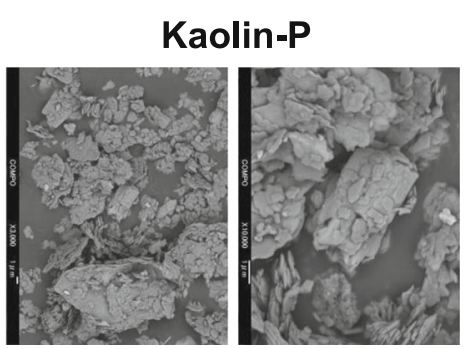

Kaolin-P

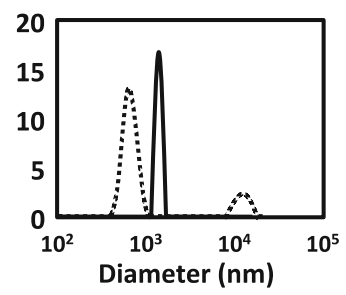

$\cdots \cdots . .0 .5 \mathrm{mg} / \mathrm{ml}$
$-2.0 \mathrm{mg} / \mathrm{ml}$

Fig. 1 Crystal appearance and size distributions of kaolins. a SEM micrographs of kaolines obtained at E=20 kV, X 3000 (left) and X 10,000 (right). b Size distributions of kaolins. Kaolins were suspended in saline containing 0.05\% Tween 80 at a concentration of 0.5 and $2.0 \mathrm{mg} / \mathrm{mL}$ (dashed line and solid line, respectively) with 10 min sonication 
$83.7 \mathrm{~nm}$, respectively (Fig. 1b). The size distributions of these two kaolins were not different from each other. Moreover, the zeta-potentials were $-8.29 \mathrm{mV}$ for kaolin-S and $-21.73 \mathrm{mV}$ for kaolin-P.

\section{DNA damage in the lungs of mice induced by intratracheal instillation of kaolins}

In order to evaluate the effect of the physicochemical character of kaolins on DNA damaging potency, kaolins were intratracheally instilled to ICR mice, and comet assay was applied to the lungs. Both kaolins significantly induced DNA damage in the lungs of the mice, however the DNA damaging potency of kaolin-P was much stronger than that of kaolin-S (Fig. 2). At a dose of $0.2 \mathrm{mg} / \mathrm{mouse}$, the tail intensities of kaolin-S and -P were $5.50 \pm 1.38$ and $13.74 \pm 1.23$, respectively. On the other hand, we examined the effects of different exposure times for not only $3 \mathrm{~h}$ but also $24 \mathrm{~h}$. DNA damage induced by kaolin did not change either for 3 or $24 \mathrm{~h}$ (data not shown).

\section{Incorporation rates of kaolin in mammalian cells}

Although the size distribution was almost the same, in vivo genotoxic potency was significantly different between kaolin-S and $-\mathrm{P}$. In order to clarify the mechanisms of this finding, we examined incorporation rates of both kaolins using cultured mammalian cells. After exposure of both kaolins to A549 cells derived from lung epithelial cells, or RAW264 cells derived from macrophage-like cells, incorporation rates into the cells were

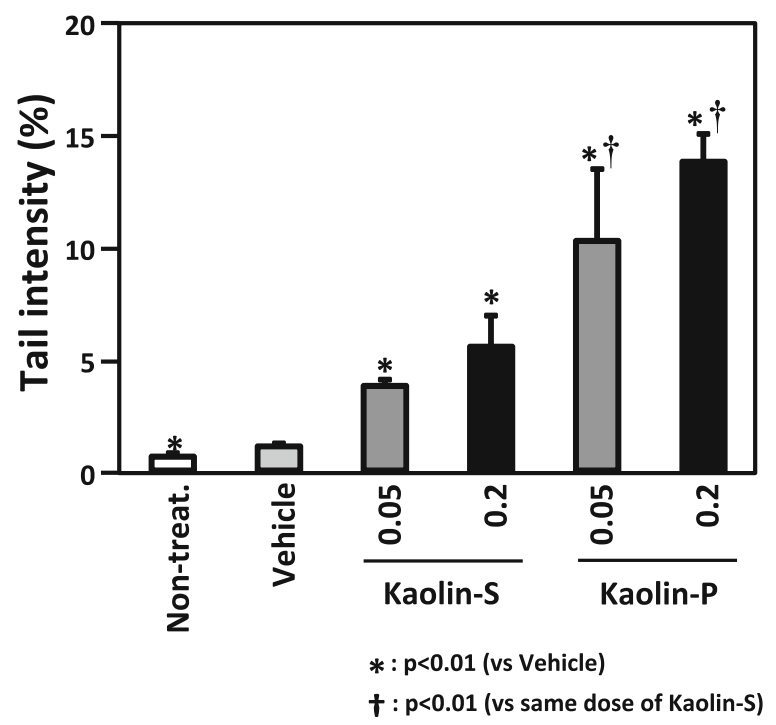

Fig. 2 DNA damage in the lungs of mice intratracheally instilled with kaolins. ICR mice were intratracheally instilled with 0.05 and $0.2 \mathrm{mg} / \mathrm{mouse}$ of two kinds of kaolin. After $3 \mathrm{~h}$ of administration, the DNA damage in the lungs of the mice was analyzed using comet assay. The values represent the mean of five animals \pm SD analyzed by FCM analysis. Even though both kaolins were incorporated into both A549 and RAW264 cells in a dose(Fig. 3a) and time- (Fig. 3b) dependent manner, the incorporation rate was greater in kaolin-P than in kaolin-S. Moreover, both kaolins were aggressively incorporated into RAW264 cells compared with A549 cells.

\section{Intercellular ROS generation}

In order to verify the oxidative stress status, A549 and RAW264 cells were treated with both kaolins at a dose of $100 \mu \mathrm{g} / \mathrm{mL}$ for 30, 60 and $180 \mathrm{~min}$. ROS generation was subsequently analyzed by using FCM with 2',7'dichlorodihydrofluorescin (DCFH) fluorescence. As shown in Fig. 4, the percentage of ROS generating cells increased up to 30 or $60 \mathrm{~min}$ then reached a plateau in RAW264 cells. Moreover, the rate of ROS positive cells was much greater with kaolin-P compared to kaolin-S, being in accordance with incorporation rates of these kaolins (Fig. 3b). In contrast, almost no ROS generating cells were observed in A549 cells exposed to either kaolin, whereas both kaolins were actually incorporated into A549 cells (Fig. 3b).

\section{Inflammatory cytokines released from RAW264}

When macrophage cells are exposed to exogenous materials, those cells were thought to release inflammatory cytokines such as interleukin-1 $\beta$ (IL-1 $\beta$ ) and tumor necrosis factor- $\alpha$ (TNF- $\alpha)$ [13]. Thus, concentrations of IL$1 \beta$ and TNF- $\alpha$ in culture supernatants of RAW264 were quantified by the ELISA method. When RAW264 cells were exposed to $100 \mu \mathrm{g} / \mathrm{mL}$ of kaolins for $24 \mathrm{~h}$, the concentrations of IL- $1 \beta$ and TNF- $\alpha$ were significantly increased (Fig. 5). In the case of IL-1 $\beta$, the value was significantly elevated by kaolin-P treatment rather than kaolin-S treatment. Similarly, the value of TNF- $\alpha$ concentration was elevated by kaolin-P rather than kaolin-S treatment, but not statistically significant.

Interaction between epithelial cells and macrophage cells In order to confirm the effect of kaolin-incorporating RAW264 cells on genotoxicity against A549, these two kinds of cells were co-cultured, as described in Materials and Methods (Scheme 1). Only RAW264 cells were exposed to $100 \mu \mathrm{g} / \mathrm{mL}$ of kaolins for $24 \mathrm{~h}$, then ROS generation in A549 cells was analyzed by the FCM method. As shown in Fig. 6, ROS-generating A549 cells increased in the presence of kaolin-exposed RAW264 cells, and ROS generating potency was much greater with kaolin-P compared to kaolin-S. DNA damage in A549 was also examined by in vitro comet assay. In the case of single culture, the tail intensity observed in A549 cells was slightly elevated by exposure to both kaolins, whereas the tail intensity observed in A549 cells was significantly elevated in the co-culture system, and kaolin-P induced high DNA damage compared to kaolin-S in both culture 

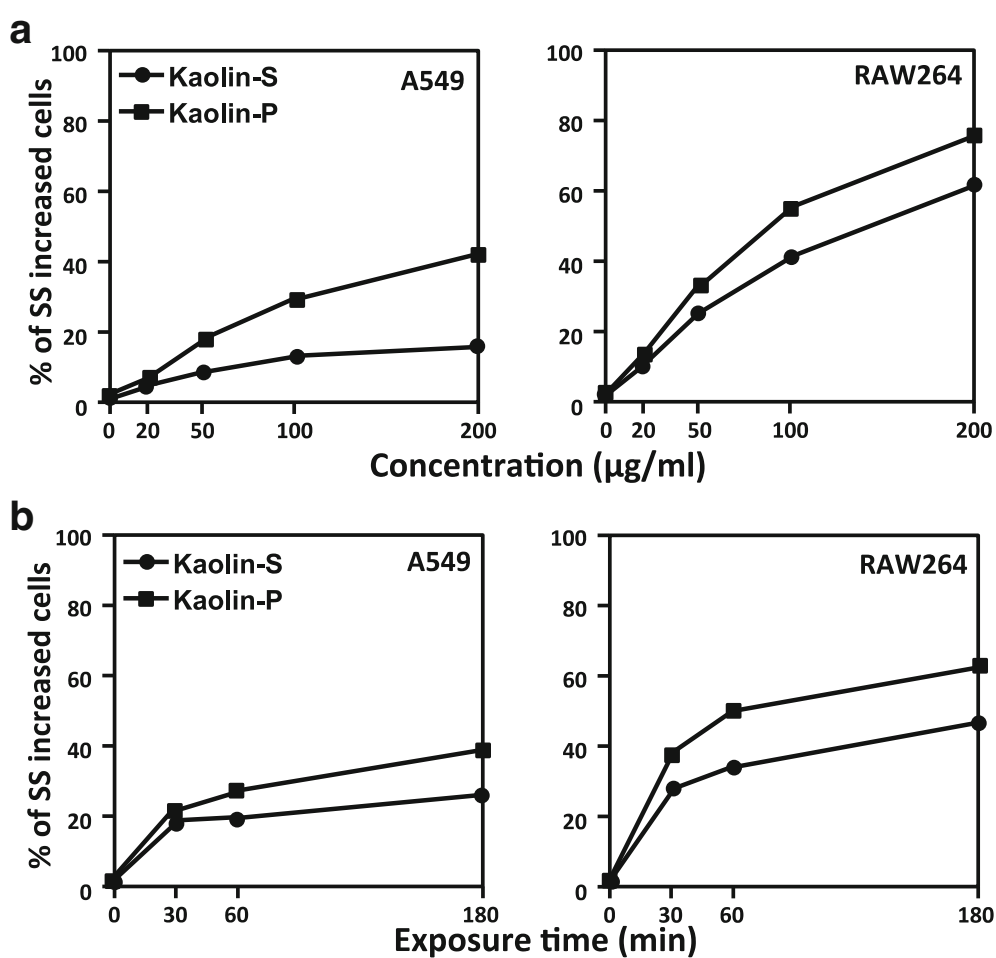

Fig. 3 FCM analysis of incorporation rates of kaolins into mammalian cells. A549 and RAW264 cells were treated with two kinds of kaolin at several doses (20, 50, 100 and $200 \mathrm{\mu g} / \mathrm{mL}$ ) for 30, 60 and $180 \mathrm{~min}$. FCM analysis was applied to the cells to examine the incorporation rates. a Dose-dependent incorporation of kaolins (time duration was $180 \mathrm{~min}$ ). b Time-dependent incorporation of kaolins (dose was $100 \mu \mathrm{g} / \mathrm{mL}$ )

systems (Fig. 7). Moreover, to determine the oxidative DNA damage, comet assay with formamidopyramidineDNA glycosylase (FPG) protein was performed. DNA damage induced by both kaolins did not increase with FPG treatment under single-culture conditions (Fig. 7a). These results suggest that these kaolins were not capable of inducing ROS-dependent DNA damage in A549 cells, in a single-culture system. On the other hand, the tail intensity was largely increased in the presence of FPG treatment with both kaolins under co-culture conditions, therefore it is suggested that kaolin may induce oxidative DNA damage in epithelial cells through activation of macrophages.

\section{Discussion}

We found that physicochemical characters, such as surface structure and zeta-potential, but not size, were different between two kinds of kaolin (kaolin-P and kaolin-S). It

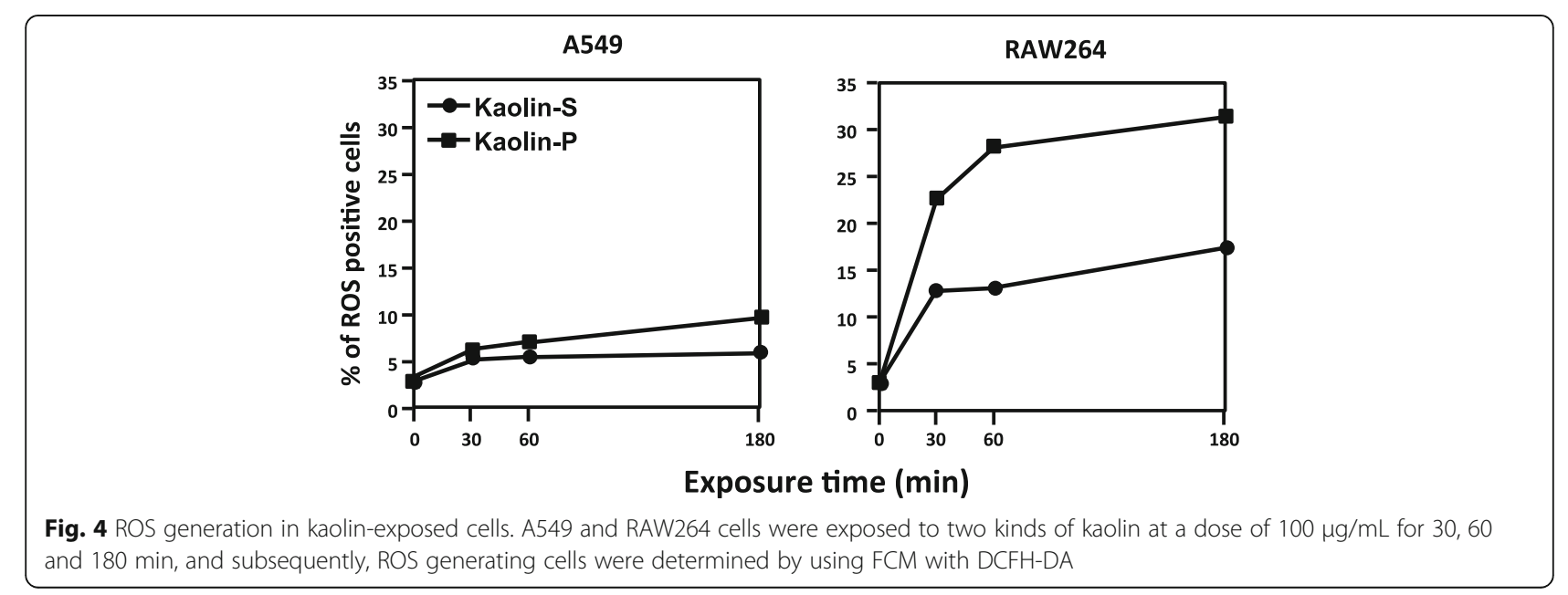



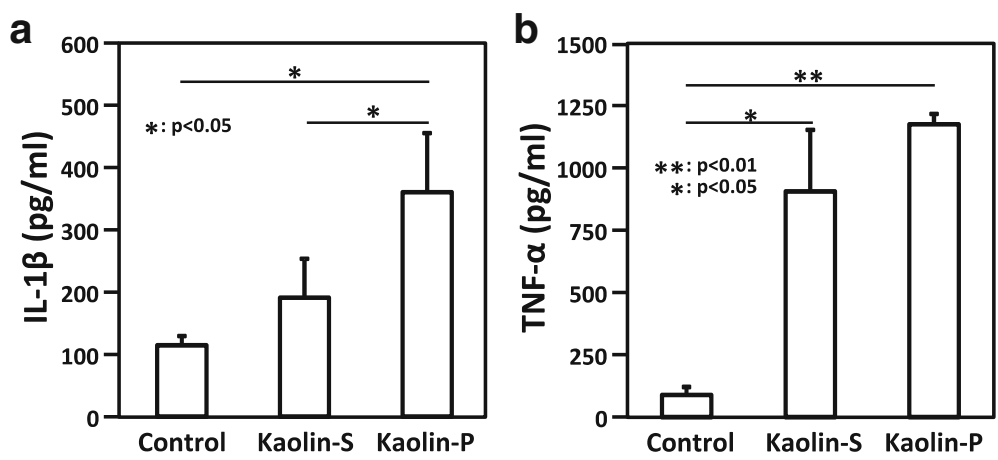

Fig. 5 Generation of inflammatory cytokines. RAW264 cells were exposed to $100 \mu \mathrm{g} / \mathrm{mL}$ of kaolins for $24 \mathrm{~h}$, and the concentrations of IL-1 $\beta$ and TNF- $a$ in culture supernatants were measured by the ELISA method. Control represents treatment with saline containing $0.05 \%$ of Tween 80. a IL-1 $\beta$. b TNF- $\alpha$. The values represent the mean of 3 independent studies \pm SD

has been reported that toxicity induced by fine particles is influenced by their physicochemical differences [4-9], thus we examined and compared the genotoxicity of these two kaolins. In vivo DNA damaging potency was apparently different for each one, and kaolin-P especially showed much more potent genotoxicity. In order to understand the reason for the differences of genotoxic potency among these kaolins, we examined incorporation rate, ROS generation and inflammatory cytokine production by in vitro systems using A549 and RAW264 cells. We have previously reported that accumulation of nitrotyrosine was observed in macrophages and alveolar epithelial cells in the lungs of mice intratracheally instilled with kaolin, thus inflammation would be partly be

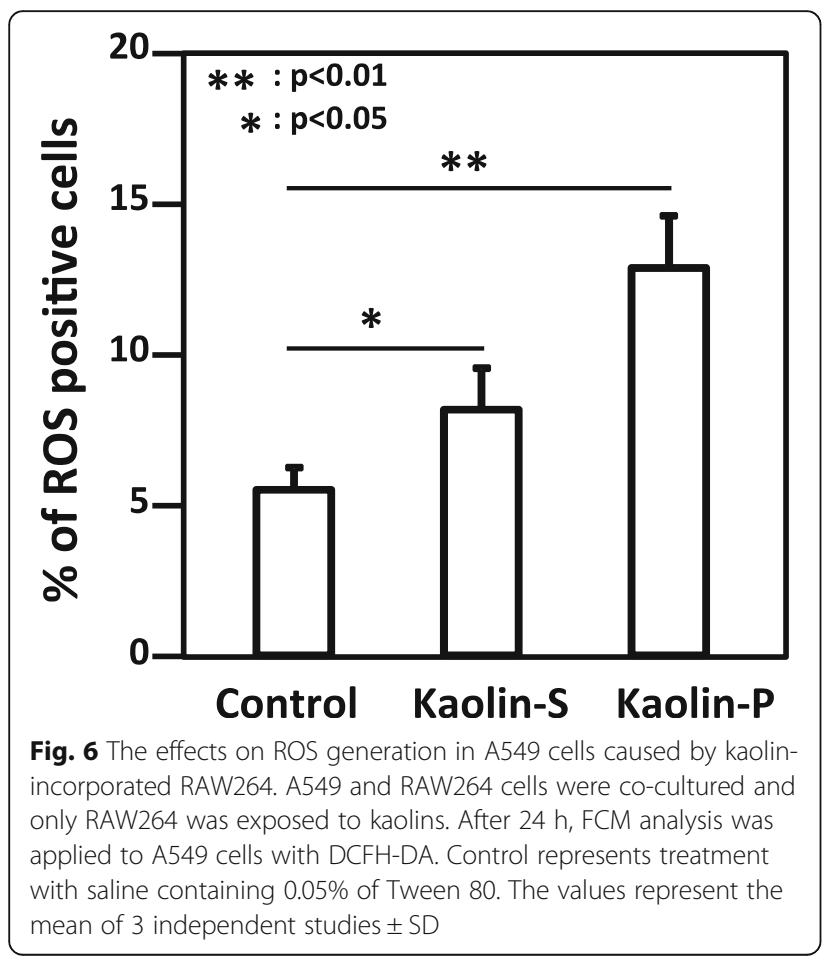

involved in the appearance of genotoxicity [3]. Therefore, we used these two types of cultured mammalian cells, lung epithelial cells (A549) and macrophage-like cells (RAW264). In the FCM analysis, RAW264 cells strongly incorporated both kaolins compared to A549 cells. Among these different commercial products of kaolins, kaolin-P and -S, kaolin-P was more aggressively incorporated into both cells. Similarly, ROS generation was markedly observed in RAW264 cells whereas almost no ROS generation was observed in A549 cells. Especially for kaolin-P exposure to RAW264 cells, the percentage of ROS positive cells was significantly increased. Kaolin-P demonstrated markedly higher values in all assays in comparison with kaolin-S. There were no differences in the aggregation sizes of both kaolins, whereas the absolute value of zeta-potential, an indicator of surface electric charge, of kaolin-P was higher than that of kaolin-S. Thus, differences of surface electric charge may contribute to incorporation into cells. It is thought that nanomaterials that have high absolute zeta-potential values are likely to spread in suspension. Actually, the higher the negative charge of silver nanoparticles the stronger the toxicity in cultured cells [5]. These results predicted that kaolin-P is likely to spread in suspension relative to kaolin-S. Therefore, mammalian cells might more easily incorporate kaolin-P compared with kaolin-S. Actually, Suzuki et al. reported that the smallest titanium dioxide $\left(\mathrm{TiO}_{2}\right)$ nanoparticle was most frequently incorporated into $\mathrm{CHO}$ cells [4]. However, detailed mechanisms for genotoxicity differences of these kaolins are not fully understand yet. Therefore further study is needed.

Many studies showed that genotoxic effects of fine particulate matter, including nanomaterials, were correlated with ROS generation [14-17]. It has been known that macrophages, immune phagocytes, produce ROS through the activation of NADPH oxidase (Nox) on endosomal membrane when macrophages incorporate exogenous materials [18-20]. Dostert et al. reported that 


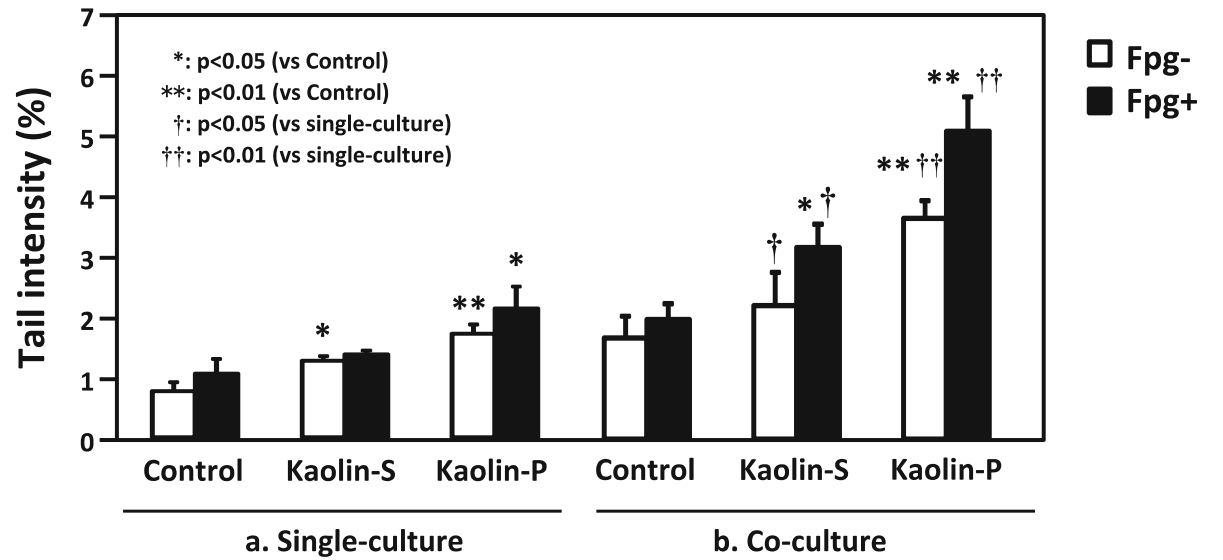

Fig. 7 The effects on DNA damage in A549 cells co-cultured with kaolin-incorporated RAW264 cells. A549 was co-cultured with or without RAW264 cells, DNA damage in A549 cells was analyzed using comet assay with FPG protein. Kaolins were exposed to A549 cells (a) or RAW264 cells (b) at a dose of $100 \mu \mathrm{g} / \mathrm{mL}$ for $60 \mathrm{~min}$. Control represents treatment with saline containing 0.05 of Tween 80 . The open and closed columns represent the absence and the presence of FPG, respectively. The values represent the mean of 3 independent studies \pm SD

ROS generation was observed in human macrophage THP-1 cells exposed to asbestos, and treatment with diphenylene iodonium and apocynin, Nox inhibitors, inhibited the ROS generation in THP-1 cells [21]. In the present study, we used RAW264 cells as immune system cells, therefore it is suggested that ROS generated by kaolin might be in the same manner as THP-1 cells. In contrast to RAW264 cells, lung epithelial cells, A549, showed little generation of ROS by either kaolin exposure (Fig. 4). Because limited incorporation rates of kaolin were observed in A549 cells, this would be the one of the reasons for the limited increase of ROS generation in A549 cells after exposure to kaolin. Moreover, we demonstrated inflammatory cytokines, such as IL-1 $\beta$ and TNF- $\alpha$, were produced by kaolin-exposed RAW264 cells. It is reported that asbestos and silica nanoparticles activated Nlrp3 inflammasome in macrophage cells, subsequently the macrophage released IL-1 $\beta$ out of cells $[21,22]$. Also, since $N$-acetyl-L-cysteine (NAC) and (2R, 4R)-4-aminopyrolidine-2,4-dicarboxylate (APDC), a ROS inhibitor, decreased the release of IL-1 $\beta$ induced by asbestos, ROS is thought to be correlated with the generation of IL-1 $\beta$ through the activation of Nlrp3 inflammasome [21, 22]. On the other hand, Li et al. reported that intracellular ROS in A549 cell was increased by treatment with IL-1 $\beta$ [23]. Also, it was noted that IL-1 $\beta$ induced superoxide through the activation of Nox [24].

As mentioned above, ROS was considered to be an agent of nanomaterial-induced DNA damage. In fact, we previously demonstrated that kaolin induced oxidative DNA adducts such as 8-oxodG in the lungs of mice [3]. Therefore, we predicted that oxidative DNA damage in alveolar epithelial cells was induced by kaolin-phagocytized macrophage in an in vivo system. To verify the interaction between epithelial and macrophage cells, A549 and
RAW264 cells were co-cultured and kaolin was exposed to only RAW264 cells. In the FCM analysis, intracellular ROS generation in A549 cells under co-culture conditions was significantly increased by both kaolins exposure, although almost no ROS generation was observed under single culture conditions. Furthermore, kaolin-P induced potent ROS generation in A549 cells compared to kaolin$\mathrm{S}$, thus these effects are thought to correlate with the amount of incorporation of these kaolins. In the case of comet assay under co-culture conditions, potent DNA damage was observed in A549 cells whereas DNA damage was slightly elevated under single culture conditions. Moreover, the DNA damage observed in the co-culture system with kaolin exposure was significantly increased by FPG treatment, but not in the single culture system. This observation indicated that ROS-dependent DNA damage was induced in A549 cells in the co-culture system with kaolin exposure. From these findings, we presumed that oxidative DNA damage in A549 was induced by kaolin-phagocytized RAW264 and may be mediated by inflammatory cytokines, including IL-1 $\beta$ and/or TNF- $\alpha$. Actually, we revealed that kaolin-exposed RAW264 cells released IL-1 $\beta$ and TNF- $\alpha$.

Supporting our findings, increased ROS production and inflammatory cytokine release were induced by nanomaterial treatment [11]. In addition, it has been reported that other immune phagocytic cells, neutrophils derived from bone marrow of C57BL/6 J mice, induced oxidative DNA damage in co-cultured A549 when the neutrophils were exposed to quartz particles [25]. Based on the above, as a genotoxic mechanism of fine particulate matter, including nanomaterials, it is likely that immune phagocytic cells intake fine particulate matter that then induces oxidative DNA damage in epithelial cells via release of inflammatory cytokines. Thus, 
considering the genotoxicity of fine particulate matter, interactions between epithelial and immune cells would be very important. However, most reports describing in vitro genotoxicity of nanomaterials used single culture systems. It is thought that single culture systems were not sufficient to evaluate the genotoxicity of nanomaterials. We showed in the present study, using a co-culture of epithelial and immune cells could be used as a suitable model for evaluating lung genotoxicity of nanomaterials as an in vivo mimicking system.

\section{Conclusions}

We have demonstrated that two kinds of commercial products of kaolin with different physicochemical characters, such as surface structure and zeta-potential, revealed different genotoxic potency in vivo. Based on in vitro analysis, this genotoxic potency might be influenced by ease of uptake into immune cells. Mechanisms of kaolin genotoxicity against epithelial cells are suggested to be through the activation of macrophage cells. Namely, immune phagocytic cells ingested kaolin then induced oxidative DNA damage in epithelial cells via release of inflammatory cytokines, such as IL-1 $\beta$ and TNF- $\alpha$. Therefore, it is thought that interactions between epithelial and immune cells would be very important for evaluation of the genotoxicity of fine particulate matter. We also showed here, co-culture models of epithelial and immune cells could be used as suitable models for evaluation of lung genotoxicity of fine particulate matter, including nanomaterials, as in vivo mimicking systems.

\section{Acknowledgments}

We thank Mr Naoaki Uchiya for his excellent technical assistance.

\section{Funding}

This study was supported by Research on Global Health Issues (U.S.-Japan Cooperative Medical Sciences Program) from the Japan Agency for Medical Research and Development, AMED, for Research on Risk of Chemical Substances from the Ministry of Health, Labour, and Welfare of Japan. The study was also supported by a grant from the Japan Chemical Industry Association (JCIA) Long-range Research Initiative (LRI).

\section{Availability of data and materials}

All data generated or analyzed during this study are included in this published article.

\footnotetext{
Authors' contributions

TK performed the comet assay, FCM analyses for incorporation and ROS generation, ELISA for production of inflammatory cytokines and drafted the manuscript. TT carried out the FCM analyses for incorporation. Analyses of size distribution and agglomeration state of particles were conducted by MW. YI, SM and YT conceived and supervised the study. All authors read and approved the final manuscript.
}

\section{Competing interests}

The authors declare that they have no competing interests.

\section{Consent for publication}

Not applicable.

\section{Ethics approval}

All animal work was conducted in accordance with the "Guidelines for Animal Experiments in the National Cancer Center" and approved by the Committee for Ethics of Animal Experimentation of the National Cancer Center.

\section{Author details}

'Division of Carcinogenesis and Cancer Prevention, National Cancer Center Research Institute, 1-1 Tsukiji 5-chome, Chuo-ku, Tokyo 104-0045, Japan. ${ }^{2}$ Graduate School of Food and Nutritional Sciences, University of Shizuoka, 52-1, Yada, Shizuoka 422-8526, Japan. ${ }^{3}$ Division of Materials Science and Engineering, Graduate School of Engineering, Yokohama National University, Hodogaya-ku, Yokohama, Japan. ${ }^{4}$ Present Address: National Institute of Occupational Safety and Health, Nagao 6-21-1, Tama-Ku, Kawasaki 214-8585, Japan.

Received: 23 September 2016 Accepted: 3 February 2017

Published online: 01 May 2017

\section{References}

1. Gupta V, Hampton MA, Stokes JR, Nguyen AV, Miller JD. Particle interactions in kaolinite suspensions and corresponding aggregate structures. J Colloid Interface Sci. 2011;359:95-103.

2. Totsuka Y, Higuchi T, Imai T, Nishikawa A, Nohmi T, Kato T, Masuda S, Kinae N, Hiyoshi K, Ogo S, Kawanishi M, Yagi T, Ichinose T, Fukumori N, Watanabe M, Sugimura T, Wakabayashi K. Genotoxicity of nano/microparticles in invitro micronuclei, in vivo comet and mutation assay systems. Part Fibere Toxicol. 2009;6:23.

3. Totsuka Y, Kato T, Masuda S, Ishino K, Matsumoto Y, Goto S, Kawanishi M, Yagi T, Wakabayashi $\mathrm{K}$. In vitro and in vivo genotoxicity induced by fullerene (C60) and kaolin. Genes Environ. 2011;1:14-20.

4. Suzuki H, Toyooka T, Ibuki Y. Simple and easy method to evaluate uptake potential of nanoparticles in mammalian cells using a flow cytometric light scatter analysis. Environ Sci Technol. 2007;41:3018-24.

5. Kaur J, Tiloo K. Evaluating cell specific cytotoxicity of differentially charged silver nanoparticles. Food Chem Toxicol. 2012;51C:1-14.

6. Gliga AR, Skoglund S, Wallinder IO, Fadeel B, Karlsson HL. Size-dependent cytotoxicity of silver nanoparticles in human lung cells: the role of cellular uptake, agglomeration and Ag release. Part Fibre Toxicol. 2014;11:11.

7. Battal D, Çelik A, Güler G, Aktaş A, Yildirimcan S, Ocakoglu K, Çömelekoğlu Ü. SiO2 Nanoparticule-induced size-dependent genotoxicity - an in vitro study using sister chromatid exchange, micronucleus and comet assay. Drug Chem Toxicol. 2015;38:196-204.

8. Sung JH, Park SJ, Jeong MS, Song KS, Ahn KS, Ryu HR, Lee H, Song MR, Cho $\mathrm{MH}$, Kim JS. Physicochemical analysis and repeated-dose 90-days oral toxicity study of nanocalcium carbonate in Sprague-Dawley rats. Nanotoxicology. 2015;9:603-12.

9. Xiong S, George S, Yu H, Damoiseaux R, France B, Ng KW, Loo JS. Size influences the cytotoxicity of poly (lactic-co-glycolic acid) (PLGA) and titanium dioxide (TiO(2)) nanoparticles. Arch Toxicol. 2013;87:1075-86.

10. Ibuki Y, Toyooka T. Nanoparticle uptake measured by flow cytometry. Methods Mol Biol. 2012;926:157-66.

11. Könczöl M, Ebeling S, Goldenberg E, Treude F, Gminski R, Gieré R, Grobéty B, Rothen-Rutishauser B, Merfort I, Mersch-Sundermann V. Cytotoxicity and genotoxicity of size-fractionated iron oxide (magnetite) in A549 human lung epithelial cells: role of ROS, JNK, and NF-KB. Chem Res Toxicol. 2011;24: 1460-75.

12. Toyoizumi T, Sekiguchi H, Takabayashi F, Deguchi Y, Masuda S, Kinae N. Induction effect of coadministration of soybean isoflavones and sodium nitrite on DNA damage in mouse stomach. Food Chem Toxicol. 2010;48: 2585-91.

13. Scherbart AM, Langer J, Bushmelev A, van Berlo D, Haberzettl P, van Schmidt AM, Rose CR, Schins RP, Albrecht C. Contrasting macrophage activation by fine and ultrafine titanium dioxide particles is associated with different uptake mechanisms. Part Fibre Toxicol. 2011;8:31.

14. Rubio L, El Yamani N, Kazimirova A, Dusinska M, Marcos R. Multi-walled carbon nanotubes (NM401) induce ROS-mediated HPRT mutations in Chinese hamster lung fibroblasts. Environ Res. 2016;146:185-90.

15. Platel A, Carpentier R, Becart E, Mordaca G, Betbeder D, Nesslany F. Influence of the surface charge of PLGA nanoparticles on their in vitro 
genotoxicity, cytotoxicity, ROS production and endocytosis. J Appl Toxicol. 2016;36:434-44.

16. Kansara K, Patel P, Shah D, Shukla RK, Singh S, Kumar A, Dhawan A. TiO2 nanoparticles induce DNA double strand breaks and cell cycle arrest in human alveolar cells. Environ Mol Mutagen. 2015;56:204-17.

17. Martin LD, Krunkosky TM, Dye JA, Fischer BM, Jiang NF, Rochelle LG, Akley $\mathrm{NJ}$, Dreher KL, Adler KB. The role of intracellular redox imbalance in nanomaterial induced cellular damage and genotoxicity: a review. Environ Mol Mutagen. 2015;56:111-24.

18. Kermanizadeh A, Chauché C, Brown DM, Loft S, Møller P. The role of reactive oxygen and nitrogen species in the response of airway epithelium to particulates. Environ Health Perspect. 1997;105 Suppl 5:1301-7.

19. Forman $\mathrm{HJ}$, Torres $\mathrm{M}$. Reactive oxygen species and cell signaling: respiratory burst in macrophage signaling. Am J Respir Crit Care Med. 2002;166:54-8.

20. Forman HJ, Torres M. Signaling by the respiratory burst in macrophages. IUBMB Life. 2001;51:365-71.

21. Dostert C, Pétrilli V, Van Bruggen R, Steele C, Mossman BT, Tschopp J. Innate immune activation through Nalp3 inflammasome sensing of asbestos and silica. Science. 2008;320:674-7.

22. Yazdi AS, Guarda G, Riteau N, Drexler SK, Tardivel A, Couillin I, Tschopp J. Nanoparticles activate the NLR pyrin domain containing 3 (NIrp3)

inflammasome and cause pulmonary inflammation through release of IL-1a and IL-13. Proc Natl Acad Sci U S A. 2010;107:19449-54.

23. Li WJ, Wang TK. Calcitonin gene-related peptide inhibits interleukin-1 betainduced interleukin-8 secretion in human type II alveolar epithelial cells. Acta Pharmacol Sin. 2006;27:1340-5.

24. Brigelius-Flohé R, Banning A, Kny M, Böl GF. Redox events in interleukin-1 signaling. Archives of Biochemistry and Biophysics. 2004;423(1):66-73.

25. van Berlo D, Wessels A, Boots AW, Wilhelmi V, Scherbart AM, Gerloff K, van Schooten FJ, Albrecht C, Schins RP. Neutrophil-derived ROS contribute to oxidative DNA damage induction by quartz particles. Free Radical Biology and Medicine. 2010;49(11):1685-1693.

\section{Submit your next manuscript to BioMed Central and we will help you at every step:}

- We accept pre-submission inquiries

- Our selector tool helps you to find the most relevant journal

- We provide round the clock customer support

- Convenient online submission

- Thorough peer review

- Inclusion in PubMed and all major indexing services

- Maximum visibility for your research

Submit your manuscript at www.biomedcentral.com/submit

Biomed Central 